\title{
PENGARUH KEMAMPUAN INDIVIDUAL MENILAI INFORMASI TERHADAP MINAT MAHASISWA AKUNTANSI DALAM MENGGUNAKAN INTERNET SEBAGAI SUMBER PUSTAKA
}

(Studi Kasus pada Universitas Bandar Lampung)

\author{
Achmad Subing \\ Andrian K \\ Goenawan
}

\begin{abstract}
The purpose of the study is to analyze the influencing factors student intention to use the internet as a source or reference literature, namely the ability of the individual (computer self-efficacy and knowledge of search domain). This study uses TAM (Technology Acceptance Model) as a basic research model and incorporate TPB (Theory of Planned Behavior) to complete the TAM. Based on the problems and research objectives the research hypothesis posed is individual ability (computer selfefficacy and knowledge of search domain) in assessing influential information interests against positive and significant of accounting students using the internet as a source library with perceived of use for mediation. The method study is a study stastistical. Crystallization rate is formalized or explanatory research, which is a structured research began with the hypothesis put forward or by using questions. The method is a library and field research. The research literature (library) aims to find a theoretical basis supporting this research, field research while aiming to obtain empirical data to test the hypothesis. Data obtained by distributing 100 questionnaires overall in the Faculty of Economics, University of Bandar Lampung Accounting Department and analysis of existing data is done with the help of SPSS version 17.0.
\end{abstract}

Keyword: Individual ability, computer self-efficacy Technology Acceptance Model.

\section{LATAR BELAKANG}

Dewasa ini arus reformasi dan globalisasi telah memasuki seluruh bidang kehidupan masyarakat seperti bidang politik, ekonomi, sosial, pendidikan, dan hiburan. Informasi yang dibutuhkan berupa lisan maupun tertulis. Namun informasi itu tidak dapat kita terima mentah - mentah, tetapi kita harus cermat dalam mengelola informasi yang kita dapat, sehingga informasi tersebut dapat bermanfaat sesuai dengan yang kita inginkan dan kita perlukan. Kemampuan untuk mengelola informasi secara efektif di dalam sebuah organisasi sangat penting karena dapat menjadi dasar untuk memperoleh keunggulan kompetitif. Informasi telah menjadi aktiva tidak berwujud, yang jika dikelola dengan baik, dapat digunaan untuk meningkatkan sumber - sumber perusahaan lainnya. Karena itu banyak perusahaan yang mulai mengembangkan dan memberikan perhatian khusus pada teknologi informasi sebagai sumber yang memfasilitasi pengumpulan dan penggunaan informasi secara efektif. Jaringan komputer dapat diartikan sebagai sebuah rangkaian dua atau lebih komputer. Komputer- 
komputer ini akan dihubungkan satu sama lain dengan sebuah sistem komunikasi. Dengan jaringan komputer ini dimungkinkan bagi setiap komputer yang terjaring di dalamnya dapat saling tukar-menukar data, program, dan sumber daya komputer lainnya seperti media penyimpanan, printer, dan lain-lain. Jaringan komputer yang menghubungkan komputerkomputer yang berada pada lokasi berbeda dapat juga dimanfaatkan untuk mengirim surat elektronik (e-mail), mengirim file data (upload) dan mengambil file data dari tempat lain (download), dan berbagai kegiatan akses informasi pada lokasi yang terpisah.

Tujuan utama dari sebuah jaringan komputer adalah sharing resource (sumber daya), dimana sebuah komputer dapat memanfaatkan sumber daya yang dimiliki komputer lain yang berada dalam jaringan yang sama. Perkembangan teknologi komunikasi data dan jaringan komputer dewasa ini sudah tidak terbatas lagi hanya pada komputer. Berbagai perangkat teknologi komunikasi yang hadir saat ini berkembang mengikuti perkembangan teknologi komputer, banyak diantaranya mengintegrasikan perangkat komputer seperti mikroprosesor, memori, display, storage, dan teknologi komunikasi ke dalamnya padahal dulunya teknologi ini dikembangkan untuk komputer yang dapat kita temui saat ini sudah ikut digunakan pada teknologi jaringan komputer.

Sedangkan internet, yang berasal dari kata interconnected-networking adalah rangkaian komputer yang terhubung di dalam beberapa rangkaian. Manakala Internet ialah sistem komputer umum, yang berhubungan secara global dan menggunakan TCP/IP sebagai protokol pertukaran paket (packet switching communication protocol). Kehadiran internet telah mengubah paradigma bagaimana manusia mendapatkan pengetahuan. Sebelum internet berkembang, pengetahuan pada umumnya didapat melalui koran, majalah, radio, buku, dan juga di bangku sekolah. Dengan hadirnya media internet, keterbatasan-keterbatasan media lainnya diharapkan mampu diatasi oleh internet.

Manfaat internet dapat terasa di berbagai kalangan seperti bagai para peneliti, pengajar, pelajar, maupun mahasiswa. Mereka umumnya memanfaatkan internet untuk menelusuri literatur, berkomunikasi dengan rekan sejawat, juga mungkin untuk mencari hiburan. Bagi pengusaha, internet umumnya dimanfaatkan untuk kepentingan bisnis, antara lain untuk berkomunikasi dengan rekanan dan bertransaksi. Beragamnya motif menggunakan internet tentunya memberikan pengaruh yang beragam kepada pengguna. Berkembangnya informasi dan internet itu sendiri tentu akan menyebabkan terjadinya kelimpahan informasi (information overload) atau kebingungan pengguna dalam memilih, menyaring, dan menilai informasi yang ditemukan di internet sehingga akan mempengaruhi kepuasan mereka.

Tabel 1

Jumlah Pengguna Internet di Dunia pada Tahun 2007

\begin{tabular}{|l|c|}
\hline \multicolumn{1}{|c|}{ NEGARA } & JUMLAH (ORANG) \\
\hline Asia & 578.538 .257 \\
\hline Afrika & 51.065 .630 \\
\hline Amerika Latin / Karibia & 139.009 .209 \\
\hline Amerika Utara & 248.241 .969 \\
\hline Eropa & 384.633 .765 \\
\hline Timur Tengah & 41.939 .200 \\
\hline Oseania / Australia & 20.204 .331 \\
\hline DUNIA ( juni 2008 ) & 1.463 .632 .261 \\
\hline
\end{tabular}

Sumber : World Internet Statistic 2007 
Perkembangan dan jumlah pengguna internet di dunia sangatlah cepat hal ini terbukti dengan melihat data pemakaian internet berdasarkan data desember 2007 dari World Internet Statistic, total pengguna internet dunia adalah 1,4 milyar orang dengan pertumbuhan $290 \%$ selama 8 tahun terakhir pada tabel 1 diatas. Sedangkan perkembangan internet di Indonesia pada tahun 2007, sekitar 25 juta orang Indonesia menggunakan internet. Rata-rata tumbuh lebih tiga juta pengguna internet tiap tahun dalam 10 tahun terakhir. Pengguna internet di Indonesia hanya tumbuh 8,9 \% tapi mencapai 20 juta orang. Pengguna internet itu berusia 10-39 tahun. Mereka bersentuhan dengan internet di kafe, sekolah atau kampus, tempat kerja, dan rumah. Sampai dengan 20 tahun ke depan, generasi internet inilah yang akan mewarnai Indonesia.

Melihat data-data internetworldstats.com pada 2007, dapatlah dikatakan bahwa jumlah pengguna internet merupakan sisi Indonesia yang membanggakan. Penetrasinya memang masih rendah, hanya 8,5 persen dari total populasi, jauh tertinggal dari bangsabangsa maju seperti Jepang (68,7 persen) atau bahkan Malaysia (60 persen). Tapi dibanding India, salah satu raksasa ekonomi dunia, penetrasi Indonesia lebih baik. Asia merupakan kawasan pengguna internet terbesar di dunia, 510 juta, mengalahkan Eropa dan Amerika Utara. Dari segi jumlah, pengguna internet Indonesia merupakan ketiga terbesar di Asia setelah Jepang dan Cina. Jumlah 31,5 juta pengguna internet di Indonesia memang bukan jumlah yang sedikit. Jumlah itu jauh lebih besar dari seluruh penduduk satu benua Australia.

Fakta dan statistik perkembangan internet khususnya di Indonesia tahun 2008 (updated Juni 2008), sebagai berikut:

- Pengguna internet tahun $2000 \quad: 2.000 .000$

- Pengguna internet sekarang

- Presentase pengguna internet

- Presentase pengguna di Asia

: 25.000 .000

- Pertumbuhan dari tahun 2000-2008

: $10 \%$ dari total penduduk

: $4.3 \%$

: $1150 \%$

Dari data di atas, menjelaskan bahwa anda termasuk 1 dari 25 juta orang pengakses internet yaitu 10,5\% dari total penduduk 237,5 juta jiwa di tahun 2008. Berarti masih ada $89,5 \%$ atau sejumlah 212,5 juta orang yang belum mengenal internet. Dan diperkirakan tahun 2010 ini akan naik sebesar $60 \%$ menjadi 55 juta pengguna. Kenaikan yang signifikan ini diyakini karena infrastruktur untuk tersedianya internet di Indonesia semakin hari akan semakin mudah dan murah. Perkiraan resmi dari APJII terhadap jumlah pelanggan dan pemakai internet selama ini dan perkiraan sampai akhir tahun 2007 adalah sesuai dengan tabel 2 berikut ini:

Tabel 2

Perkiraan Jumlah Pelanggan dan Pemakaian Internet dari Tahun 1998 - 2007

\begin{tabular}{|c|c|c|}
\hline TAHUN & PELANGGAN & PEMAKAI \\
\hline 1998 & 134.000 & 512.000 \\
\hline 1999 & 256.000 & 1.000 .000 \\
\hline 2000 & 400.000 & 1.900 .000 \\
\hline 2001 & 581.000 & 4.200 .000 \\
\hline 2002 & 667.002 & 4.500 .000 \\
\hline 2003 & 865.706 & 8.080 .534 \\
\hline 2004 & 1.087 .428 & 11.226 .143 \\
\hline 2005 & 1.500 .000 & 16.000 .000 \\
\hline 2006 & 1.700 .000 & 20.000 .000 \\
\hline 2007 & 2.000 .000 & 25.000 .000 \\
\hline
\end{tabular}

Sumber : World Internet Statistic 2007 
Meskipun perkembangan internet telah berkembang pesat di Indonesia, namun masih banyak mahasiswa yang masih enggan untuk menggunakan internet dalam melaksanakan tugas mereka. Salah satu kemungkinan yang menyebabkan keengganan adalah masalah kualitas informasi yang didapatkannya melalui media internet yang mungkin saja kurang relevan dengan informasi yang dibutuhkannya. Mahasiswa harus bisa membedakan mana informasi yang dapat dipercaya atau tidak. Masalah keengganan lainnya adalah masala ketakutan (anxiety) dan kepercayaan diri (self efficacy) dalam menggunakan internet. Kemampuan individual setiap mahasiswa berbeda sehingga cara mereka dalam mengoperasikan internet untuk mendapatkan informasi yang dibutuhkannya juga berbeda. Oleh karena itu ada beberapa mahasiswa dengan kemampuannya dalam menggunakan internet diatas rata - rata, lebih tahu bagaimana memanfaatkan internet sebagai sarana internet untuk meningkatkan kinerja pekerjaannya dan tentu saja lebih memiliki niat untuk menggunakan internet. Sedangkan untuk mahasiswa yang kurang memiliki kemampuan tersebut cenderung memiliki niat yang lebih kecil untuk menggunakan internet karena dianggap terlalu rumit dan memerlukan usaha yang lebih keras.

Masalah lainnya adalah mengenai faktor sosial, yang dalam hal ini berperan sebagai pendorong atau motivator mahasiswa dalam menggunakan internet. Mahasiswa akan memiliki niat untuk menggunakan internet jika dia merasa bahwa orang terdekatnya akan mengangap bahwa dia akan lebih berkinerja jika menggunakan internet. Faktor ini bisa berasal dari teman dekat, saran dosen atau rekan kerjanya.

\section{TELAAH LITERATUR DAN PENGEMBANGAN HIPOTENSI}

\section{Tinjauan Pustaka}

\section{Informasi}

Informasi sudah menjadi sesuatu yang sangat penting bagi kehidupan sekarang. Informasi adalah data yang telah diolah mernjadi suatu bentuk yang penting bagi si penerima dan mempunyai nilai yang nyata yang dapat dirasakan dalam keputusan - keputusan yang sekarang atau keputusan - keputusan yang akan dating Informasi merupakan kumpulan data yang dilah menjadi bentuk yang lebih berguna dan lebih berarti bagi yang menerima.

Untuk memperoleh informasi yang berguna, tindakan pertama adalah mengumpulkan data, kemudian mengolahnya sehingga menjadi informasi. Dari data - data tersebut informasi yang didapatkan lebih terarah dan penting karena telah dilampaui berbagai tahap dalam pengolahannya diantaranya yaitu pengumpulan data, data apa yang terkumpul dan menemukan informasi yang diperlukan. Berguna atau tidaknya suatu informasi tergantung dari beberapa aspek, yaitu :

1. Tujuan Penerima

Apabila informasi itu tujuannya untuk memberikan bantuan maka informasi itu harus membantu si penerima dalam usahanya untuk mendapatkan informasi tersebut.

2. Ketelitian penyampaian dan pengolahan data Penyampaian dan pengolahan data, inti dan pentingnya info harus dipertahankan.

3. WaktuInformasi yang disajikan harus sesuai dengan perkembangan informasi itu sendiri.

4. Ruang dan tempat

Informasi yang didapat harus tersedia dalam ruangan atau tempat yang tepat agar penggunaannya lebih terarah bagi si pemakai.

5. Bentuk Dalam hubungannya bentuk informasi harus disadari oleh penggunaannya secara efektif, hubungan - hubungan yang diperlukan, kecenderungan - kecenderungan dan 
bidang - bidang yang memerlukan perhatian manajemen serta menekannkan informasi tersebut ke situasi - situasi yang ada hubungannya.

6. Semantik

Agar informasi efektif, informasi harus ada hubungannya antara kata - kata dan arti yang cukup jelas dan menghindari kemungkinan salah tafsir.

\section{Kualitas Informasi}

Kualitas informasi adalah tingkat relevan (relevant), ketepatan waktu (timely), aman dan disajikan dengan rancangan informasi yang baik dalam sebuah website (Liu \& Arnett, 2000). Kualitas informasi terbaik dapat diberikan oleh internet ketika bisa didapatkan dengan mudah (tidah susah dalam pencariannya), terorganisasi (teratur), dan tersedia dalam jumlah yang banyak (Donthu dan Garcia, 1999; Peterson et al.. 1997), dalam Istianingsih dan Setyo Hari Wijanto (2008). Kualitas informasi juga dapat dilihat dengan adanya potensi menghasilkan informasi yang tidak terbatas baik dalam organisasi maupun luar organisasi (Barnes et al, 2003). Menurut Li et al. (2002), informasi yang berkualitas adalah informasi yang akurat, jelas, detil, relevan, mudah didapatkan, tepat waktu, up to date dan sesuai dengan kebutuhan pengguna. Liu dan Arnett (2000) menyatakan bahwa informasi dengan kualitas terbaik akan meningkatkan kegunaan persepsian pengguna dan meningkatkan penggunaan sistem informasi. Lin dan Lu (2000) juga menambahkan bahwa penerimaan atau penolakan pengguna atas sebuah sistem disebabkan oleh kualitas yang diberikan oleh sebuah sistem.Keandalan menurut Ikatan Akuntan Indonesia (IAI) adalah informasi memiliki kualitas andal jika bebas dari pengertian yang menyesatkan, kesalahan material, dan dapat diandalkan pemakaiannya sebagai penyajian yang tulus dan jujur (faithful representation) dari yang seharusnya disajikan atau yang secara wajar diharapkan dapat disajikan (IAI, 2002). Keandalan informasi keuangan menurut Jaggi (1985) yaitu kualitas informasi keuangan dikatakan andal apabila telah dapat mengungkapkan informasi yang yang materiil secara lengkap dan akurat mencakup dimensi penting yang relevan dari kejadian esensial. Disamping itu, telah diproses sesuai dengan prisnsip/standar yang berlaku umum, dapat diuji kebernarannya, dan bebas, baik dari bias pribadi maupun bawaan. Suatu informasi dapat dikatakan berkualitas apabila informasi itu telah sesuai dengan syarat - syarat seperti :

\section{* Akurat (accurate)}

Informasi harus bebas dari kesalahan - kesalahan dan tidak bias serta menyesatkan bagi si penerima informasi. Akurat juga berarti informasi harus jelas dalam mencerminkan maksudnya. Informasi harus akurat karena dari sumber indormasi sampai ke penerima informasi kemungkinan banyak terjadi gangguan yang dapat merubah atau merusak informasi tersebut. Komponen akurat meliputi :

- Completeness, berarti informasi yang dihasilkan atau dibutuhkan harus memiliki kelengkapan yang baik, karena bila informasi yang dihasilkan sebagian - sebagian akan mempengaruhi dalam pengambilan keputusan.

- Correctness, berarti informasi yang dihasilkan atau dibutuhkan harus memiliki kebenaran.

- Security, berarti informasi yang dihasilkan atau dibutuhkan harus memiliki kemanan

* Tepat pada waktunya (timely basis)

Informasi yang datang pada penerima tidak boleh terlambat, informasi yang sudah usang tidak akan mempunyai nilai lagi, karena informasi merupakan landasan didalam pengambilan keputusan. Bila keputusan pengambilan terlambat, maka dapat berakibat fatal untuk organisasi. Dewasa ini mahalnya nilai suatu informasi disebabkan harus 
cepatnya informasi tersebut didapat, sehingga diperlukan teknologi - teknologi mutakhir untuk mendapatkan, mengolah dan mengirimkannya.

* Relevan (relevance)

Informasi tersebut mempunyai manfaat bagi pemakainya. Relevansi informasi untuk tiap-tiap orang satu dengan yang lainnya berbeda, misalnya informasi mengenai sebab kerusakan mesin produksi kepada akuntan perusahaan adalah kurang relavan dan akan lebih relevan bila ditujukan kepada ahli teknik perusahaan. Sebaliknya informasi mengenai harga pokok produksi untuk ahli teknik merupakan informasi yang kurang relevan tetapi relevan bagi akuntan perusahaan.

* Ekonomis (economic)

Informasi yang dihasilkan mempunyai manfaat lebih besar dibandingkan dengan biaya mendapatkannya dan sebagian besar informasi tidak dapat tepat diktasir keuntungannya dengan satuan nilai uang tetapi dapat ditaksir nilai efektivitasnya.

* Mudah (easy)

Informasi mudah dipahami dan mudah diperoleh.

\section{Kemampuan individual}

Kemampuan individual dapat dibagi kedalam dua bagian, yaitu kemampuan nyata (actual ability) dan kemampuan potensial (potential ability). Kemampuan nyata (actual ability) yaitu kemampuan yang diperoleh melalui belajar (achivement atau prestasi), yang dapat segera didemonstrasikan dan diuji sekarang. Misalkan, setelah selesai mengikuti proses perkuliahan, pada akhir perkuliahan mahasiswa di uji oleh dosen tentang materi yang disampaikannya (tes formatif).

Ketika mahasiswa mampu menjawab dengan baik tentang pertanyaan dosen, maka kemampuan tersebut merupakan kemampuan nyata (actual ability). Sedangkan kemampuan potensial merupakan aspek kecakapan yang masih terkandung dalam diri individu dan diperoleh dari faktor keturunan (herediter).Pada penelitian ini ada dua kemampuan individual dalam sistem informasi akuntansi yang akan diuji, yaitu keyakianan sendiri komputer (computer self-efficacy) dan pengetahuan mengenai domain pencarian (knowledge of search domain)

\section{Computer self-efficacy}

Keyakinan-sendiri (self-efficacy) didefinisikan sebagai persepsi individual terhadap kemudahan atau kesulitan dalam melakukan perilaku atau keyakinan terhadap kemampuan sendiri untuk melakukannya. Individual-individual akan cenderung lebih puas dengan perilaku yang mereka rasa mampu untuk melakukannya dan cenderung tidak menyukainya untuk perilaku-perilaku yang mereka tidak bisa menguasainya

ada tiga faktor yang dapat mempengaruhi computer self-efficacy yaitu :

1. Dorongan dari pihak lain

Dorongan dari pihak lain mengacu pada kelompok dan menggunakan persuasi verbal.

2. Pihak lain sebagai pengguna

Seseorang dapat meningkatkan computer self-efficacy-nya karena mengobservasi dan meniru model perilaku.

3. Dukungan

Adanya dukungan dari organisasi bagi pengguna komputer dapat mengingkatkan computer self-efficacy. 


\section{Knowledge of search domain}

Domain adalah nama yang merupakan identifikasi dari satu atau lebih alamat IP. Domain memberikan kemudahan pengguna di internet untuk mengingat nama dan melakukan akses ke server yang hendak dikunjungi daripada mengingat alamat Internet Protocol. Ada beberapa istilah - istilah yang berhubungan dengan domain seperti :

- Top Level Domain

Merupakan akhiran pada suatu domain yang mengindikasikan pemilik tingkatan tertinggi domain tersebut dan jenis domain tersebut. Domain seperti ini terbatas, beberapa contohnya adalah :

$>$.gov - Government agencies (Pemerintah)

$>$.edu -Educational istitutios (Institusi pendidikan)

$>$.org - Organization(Organisasi nonprofit)

$>$.mil -Military (Militer)

$>$.com - Commercial business ( Organisasi profit/komersil)

$>$.net - Network organization (Organisasi network)

- Domain dirrect

Disebut juga URL redirect yang meneruskan dari satu alamat nama domain ke alamat nama domain lain.

- Sub domain

Nama domain tambahan yang menjadi bagian tak terpisahkan dari nama domain utama.

- Add-on domain

Nama domain yang diarahkan ke sub-direktori sebuah nama domain utama.

\section{Internet}

Secara fisik internet adalah interkoneksi antar jaringan komputer, namun secara umum internet harus dipandang sebagai sumberdaya informasi. Isi internet adalah informasi, dapat dibayangkan sebagai suatu database atau perpustakaan multimedia yang sangat besar dan lengkap. Bahkan internet dipandang sebagai dunia dalam bentuk lain (maya) karena hampir seluruh aspek kehidupan di dunia nyata ada di internet seperti bisnis, hiburan, olahraga, politik dan lain sebagainya.

\section{Theory Reasoned Action (TRA)}

TRA dikembangkan oleh Fishben dan Anzen tahun 1975 (Fichman, 1992: Schillawaert, et. al., 2001). Secara garis besar, TRA menyatakan bahwa perilaku (behavior) individu dapat diprediksi dari minat pelaku (behavior intention). Adapun minat berprilaku individu dipengaruhi oleh dua faktor, yaitu sikap terhadap perilaku (attitude toward behavior) dan norma subyektif (subjective norms). Dengan demikian, secara sederhana TRA menyatakan bahwa seseorang akan melakukan sesuatu perbuatan apabila ia memandang perbuatan tersebut positif dan bila ia percaya bahwa orang lain ingin agar ia melakukannya.

\section{Theory of Planned Behavior (TPB)}

Teori perilaku rencanaan (Theory of Planned behavior) merupakan teori hasil perkembangan dari TRA (Theory Reasoned Action). Perbedaan antara keduanya adalah pada TPB adanya penambahan pada satu variabel yaitu perceived behavior control. Pengendalian perilaku persepsian ini merupakan faktor ketiga yang diprediksi mendahului terbentuknya niat perilaku individu. Ada dua control disini, yaitu faktor kontrol internal adalah keahlian (skill), kemampuan, informasi, emosi seperti stress dan faktor eksternal termasuk diantaranya 
situasi dan faktor lingkungan. Pengendalian perilaku persepsian didefinisikan sebagai besarnya tingkat keyakinan individu untuk mengendalikan akibat dari peilaku yang dilakukan seorang individu akan memiliki niat yang kuat untuk berperilaku bila individu tersebut meyakini bahwa mereka memiliki sumberdaya dan kesempatan untuk melakukan perilaku tersebut. Demikian juga sebaliknya bila individu merasa tidak memiliki kemampuan ataupun sumber daya untuk melakukan perilaku tersebut maka intensi atau niat untuk melakukan perilaku tertentu akan rendah walaupun individu memilki sikap positif terhadap perilaku dan yakin bahwa orang lain juga melakukan perilaku yang sama. Teori ini dapat dipahami dengan lebih jelas pada gambar di bawah ini :

\section{Technology Acceptance Model (TAM)}

Model penerimaan teknologi (Technology Acceptance Model atau TAM) pertama kali diperkenalkan oleh Fred D. Davis pada tahun 1986. Teori ini merupakan hasil pengembangan dan adaptasi dari dua teori sebelumnya yaitu Theory of Reasoned Action dan Theory of Planned behavior. TAM merupakan model penerimaan suatu teknologi sistem informasi dengan dua konstruk utama yang membedakannya dengan dua teori sebelumnya. Dua konstruk utama ini adalah kegunaan pesepsian (perceived usefulness) dan kemudahan penggunaan persepsian (perceived ease of use). Dalam TAM, penerimaan individual terhadap teknologi informasi, ditentukan oleh dua konstruk tersebut.

Kegunaan persepsian (perceived usefulness) dan kemudahan penggunaan persepsian (perceived ease of use) keduanya mempunyai pengaruh ke niat perilaku (behavioral intention). Pemakai teknologi akan mempunyai niat menggunakan teknologi jka dia merasa bahwa teknologi tersebut bermanfaat baginya dan mudah dalam penggunaannya. Kegunaan persepsian (perceived usefulness) juga mempengaruhi kemudahan penggunaan persepsian (perceived ease of use) tetapi tidak sebaliknya. Pemakai sistem akan menggunakan sistem jika sistem tersebut bermanfaat tanpa baik sistem itu mudah digunakan atau tidak mudah digunakan.

Gambar 2

Technology Acceptance Model (TAM)

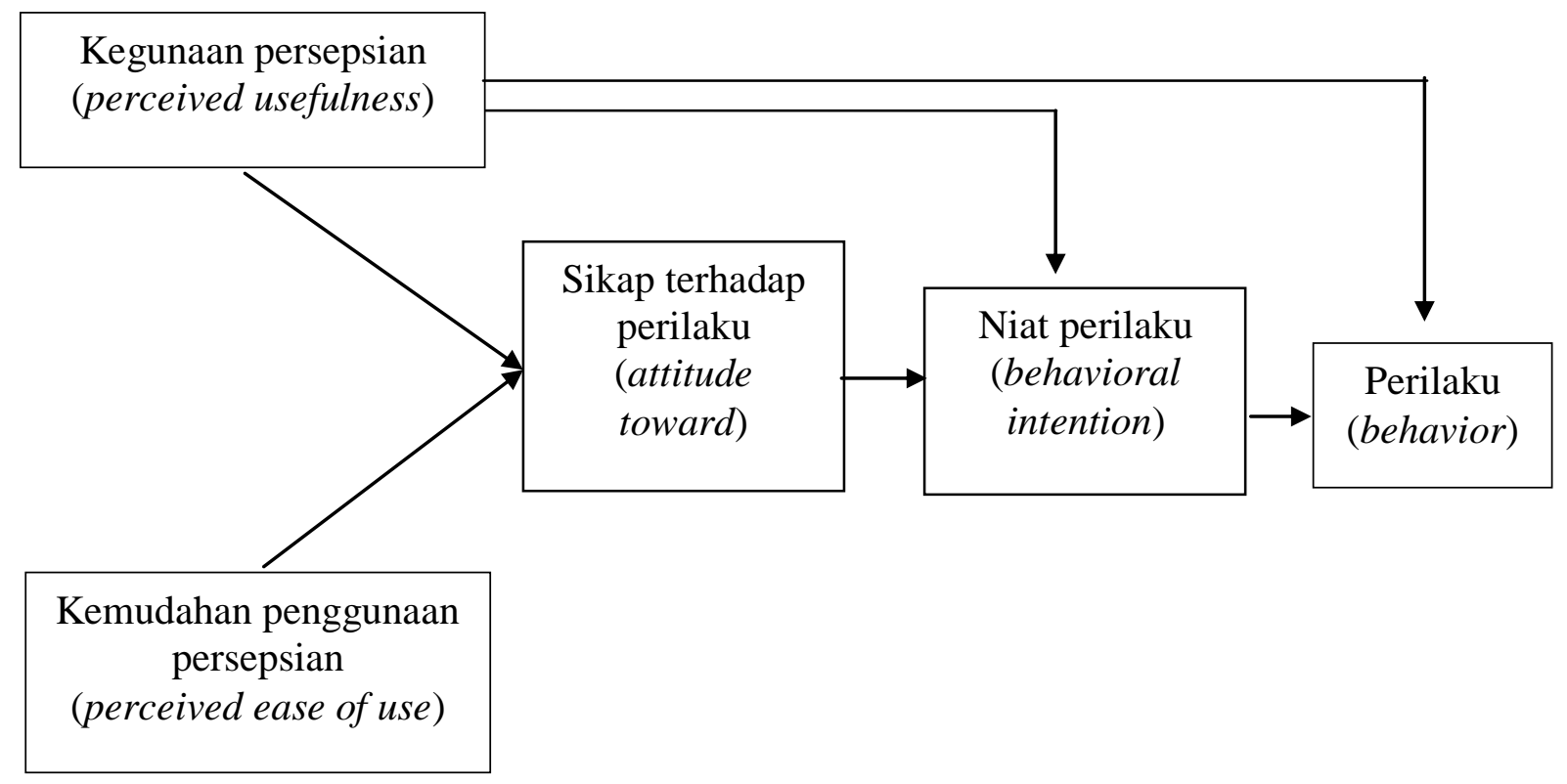




\section{Kualitas informasi}

Dalam penelitian ini, dimensi-dimensi kualitas informasi yang akan digunakan sebagai ukuran kualitas informasi dari penggunaan internet yaitu Accuracy, precision Currency, timeliness, reliability, completeness, conciseness, format dan relevance.

\section{Kemampuan individual}

\section{Computer self-efficacy}

Hubungan antara computer self-efficacy dan perceived ease of use membangun konsep dari perceived usefulness dan perceived ease of use berdasarkan pada teori selfefficacy, dan meyakini bahwa self efficacy yang didefinisikan sebagai pendapat tentang baik atau tidaknya individu dalam melakukan hal-hal yang diperlukan guna mengatasi beerbagai macam situasi atau masalah, berhubungan dengan kemudahan penggunaan persepsian (perceived ease of use). Keyakinan-sendiri computer (computer self-efficacy) memiliki pengaruh positif terhadap kemudahan penggunaan persepsian (perceived ease of use) internet sebagai bahan referensi/pustaka.

\section{Knowledge of search domain}

Oleh karena itu dapat disimpulkan bahwa latar belakang pengetahuan seseorang tentang domain pencarian informasi dapat mendukung interaksi yang lebih mudah dangan teknologi yang digunakan yang dalam hal ini adalah internet, Pengetahuan tentang domain pencarian (knowledge of search domain) memiliki pengaruh positif terhadap kemudahan penggunaan persepsian (perceived ease of use) internet sebagai bahan referensi/pustaka.

\section{Kegunaan persepsian (perceived usefulness)}

Kegunaan persepsian (perceived usefulness) adalah sejauh mana seseorang percaya bahwa menggunakan suatu teknologi akan meningkatkan kinerjanya. Dari definisi tersebut dapat diketahui bahwa kegunaan persepsian merupakan suatu kepercayaan tentang proses pengambilan keputusan. Jika seseorang merasa percaya bahwa sistem berguna maka dia akan menggunakannya. Sebaliknya jika seseorang merasa percaya bahwa sistem informasi kurang berguna maka dia tidak akan menggunakannya. Penelitian-penelitian sebelumnya menunjukan bahwa konstruk kegunaan persepsian mempengaruhi secara positif dan signifikan terhadap penggunaan sistem informasi Penelitian sebelumnya menunjukan bahwa kegunaan persepsian merupakan konstruk yang paling banyak signifikan dan penting yang mempengaruhi sikap, niat dan perilaku dalam penggunaan teknologi dibanding konstruk yang lain.

\section{Kemudahan penggunaan persepsian (perceived ease of use)}

Kemudahan penggunaan persepsian sebagai tingkat keyakinan seseorang bahwa dalam menggunakan sistem tertentu tidak diperlukan usaha yang keras. Meskipun usaha menurut setiap orang bebeda-beda tetapi pada umumnya untuk menghindari penolakan dari pengguna sistem atas sistem yang dikembangkan, maka sistem harus mudah diaplikasikan oleh pengguna tanpa mengeluarkan usaha yang dianggap memberatkan.

Kemudahan penggunaan persepsian merupakan salah satu konstruk dalam TAM yang telah diuji dalam penelitian Davis et al. (1989). Hasil penelitian tersebut menunjukkan bahwa faktor ini terbukti dapat menjelaskan alasan seseorang dalam menggunakan sistem informasi dan menjelaskan bahwa sistem baru yang sedang dikembangkan diterima oleh 
pengguna.Beberapa penelitian lainnya juga memberikan bukti mengenai pengaruh yang signifikan dari kemudahan penggunaan persepsian (perceived ease of use) terhadap niat perilaku (behavior intention) secara langsung ataupun pengaruh secara tidak langsung melalui kegunaanpersepsian (Agarwal dan Prasad, 1999; Davis et al., 1989; Hu et al., 1999; Jackson et al., 1997; Venkatesh, 1999, 2000; Venkatesh dan Davis, 1996, 2000; Venkatesh dan Morris, 2000) dalam Hong et al. (2002). Berdasarkan paparan tersebut, maka hipotesis yang diajukan dalam

Tabel 3

Paradigma Penelitian

\begin{tabular}{|l|l|l|}
\hline \multicolumn{1}{|c|}{ VARIABEL $(\mathbf{X})$} & \multicolumn{1}{c|}{ VARIABEL (Y) } \\
\hline $\begin{array}{l}\text { - Kemampuan Individual } \\
\begin{array}{l}\text { Computer Self Efficacy } \\
\text { - Knowledge Of Search } \\
\text { Domain }\end{array}\end{array}$ & $\begin{array}{l}\text { Minat Mahasiswa } \\
\text { Akuntansi Dalam } \\
\text { Menggunakan Internet } \\
\text { Sebagai Sumber Pustaka }\end{array}$ \\
\cline { 3 - 3 } & \\
\hline
\end{tabular}

\section{Metodologi Penelitian Metode Penelitian}

Motode penelitian yang digunakan dalam penelitian ini merupakan stastistical study, yaitu dilakukan pada beberapa universitas dan perguruan tinggi yang di ambil sebagai sampel. Tingkat kristalisasi penelitian adalah formalized atau explanatory, yaitu suatu penelitian yang terstruktur dimulai dengan mengemukakan hipotesis atau dengan menggunakan pertanyaan. Adapun cara penelitian adalah library dan field. Penelitian kepustakaan (library) bertujuan untuk mencari landasan teori yang mendukung penelitian ini, sedangkan penelitian lapangan bertujuan untuk mendapatkan data empiris untuk pengujian hipotesis. Dalam operasi perolehan data modus komunikasi yang dipakai adalah survey, dan sifat hubungan antara variabel adalah causal, yaitu variabel X (independent) sebagai penyebab berubahnya variabel $\mathrm{Y}$ (dependent) yang dinotasikan dengan fungsi $\mathrm{Y}=\mathrm{f}(\mathrm{Xi})$.

\section{Kriteria Responden dan penentuan Populasi}

Untuk mendapatkan data yang dibutuhkan dilakukan penelitian lapangan. Penelitian lapangan dimaksudkan untuk mendapatkan data yang akurat dan tanggapan dari responden yang tepat.Populasi adalah keseluruhan elemen (unsur, unit, individu) dari suatu himpunan dengan ciri - ciri tertentu yang sama. Adapun populasi penelitian ini adalah :

$>$ Perguruan Tinggi yang mempunyai Program Studi Akuntansi

$>$ Berlokasi di daerah Bandar Lampung

$>$ Sudah terakreditas baik

$>$ Mahasiswa merupakan pengguna internet

\section{Pengambilan Sampel}

Untuk mendapatkan data yang diperlukan,sampel ditentukan dengan proportionate stratified random sampling. Teknik ini digunakan bila populasi mempunyai anggota/unsur yang tidak homogen dan berstrata secara proporsional. Suatu organisasi yang mempunyai pegawai dari latar belakang pendidikan yang berstrata, maka populasi pegawai itu berstrata. 
Alasan utama digunakan proportionate stratified random sampling karena mahasiswa Universitas Bandar Lampung dianggap heterogen yang ada di tingkat semester 1, 2, 3, 4, 5, 6 dan 7 dalam penggunaan internet.Peneliti mengambil batasan bahwa jumlah responden ada 100 mahasiswa. Berdasarkan syarat yang dapat dilakukannya pengolahan data secara statistik dengan menggunakan program komputer Statistical Product and Service Solution (SPSS) versi 17.0.

\section{Identifikasi dan Pengukuran Variabel}

Sesuai dengan judul dalam penelitian ini, maka variabel yang diteliti terdiri dari dua variabel, yaitu variabel kemampuan individual dan minat mahasiswa akuntansi dalam menggunakan internet sebagai sumber pustaka. Kualitas informasi dan kemampuan individual merupakan variabel bebas atau independent variabel, sedangkan minat mahasiswa dalam menggunakan internet sebagai sumber pustaka merupakan variabel terpengaruh atau dependent variabel.

\section{Teknik Pengumpulan Data}

Untuk mendapatkan data yang dibutuhkan, dilakukan penelitian lapangan. Penelitian lapangan dimaksudkan untuk mendapatkan data - data yang akurat dan tanggapan dari responden yang tepat. Data yang dibutuhkan dikumpulkan melalui kuesioner yang berisi daftar pertanyaan mengenai semua variabel yang diteliti. Pengumpulan data dilakukan dengan mengantar langsung kuesioner kepada responden yang ditujukan.

\section{Teknik Pengujian Data}

Mengingat pengumpulan data dilakukan melalui kuesioner, maka kesungguhan responden dalam menjawab pertanyaan - pertanyaan merupakan hal yang penting dalam penelitian ini. Keabsahan suatu hasil penelitian sosial sangat ditentukan oleh alat pengukur yang digunakan untuk mengukur variabel - variabel penelitian. Apabila alat yang dipakai dalam proses pengumpulan data tidak valid dan tidak dapat dipercaya, maka hasil yang diperoleh tidak akan menggambarkan keadaan yang sebenarnya. Meskipun item - item pertanyaan yang digunakan dalam penelitian ini telah digunakan pada penelitian sebelumnya dan dinyatakan valid serta reliabel, tetapi item - item ini perlu di uji kembali validitas dan reabilitasnya. Pengujian kedua tes itu tersebut dilakukan dengan menggunakan bantuan program komputer SPSS versi 17.0.

\section{Teknik Pengujian Validitas}

Uji validitas dilakukan untuk mengetahui apakah alat ukur yang telah disusun benarbenar mengukur apa yang perlu diukur. Uji validitas berguna untuk menentukan seberapa cermat suatu alat melakukan fungsi ukurannya. Alat ukur validitas yang tinggi berarti mempunyai varian kesalahan yang kecil, sehingga memberikan keyakinan bahwa data yang terkumpul merupakan data yang dapat dipercaya. Dengan demikian uji validitas ini diharapkan dapat menggambarkan kekonsistenan internal (internal consistency).

\section{Teknik Pengujian Realibilitas}

Setelah dapat ditentukan bahwa pernyataan yang dibuat dalam penelitian valid, maka dilanjutkan dengan test of reability. Perhitungan reabilitas hanya dapat dilakukan dengan pertanyaan - pertanyaan yang sudah memiliki validitas. Tes ini dilakukan untuk mengetahui sejauh mana hasil jawaban responden konsisten atau stabil dari waktu ke waktu. Jika uji 
validitas menekankan pada konsistensi internal (internal consistency) butir pertanyaan dalam mengungkapkan sesuatu yang akan diukur, uji reabilitas bermaksud mengungkapkan stabilitas internal (internal stability) jawaban dalam satu faktor. Dengan kata lain, uji keandalan butir harus dilakukan sebanyak faktor tersebut.

\section{Teknik Pengujian Hipotesis}

Pada garis besarnya ada tujuan yang hendak dicapai dalam penelitian ini. Tujuan tersebut adalah untuk menguji hipotesa yang telah diajukan dalam penelitian ini. Untuk mencapai tujuan penelitian, maka data yang sudah diolah perlu dianalisa. Data tersebut diolah dengan berbagai cara sesuai dengan tujuan yang hendak dicapai. Dalam mengolah data, metode statistik yang digunakan adalah statistik deskriptif dan statistik inferen atau induktif.

Pada dasarnya yang hendak diuji adalah sejauh mana terdapat pengaruh kualitas informasi dan kemampuan individual (variabel X) terhadap minat mahasiswa akuntansi dalam menggunakan internet sebagai sumber pustaka (variabel Y). Penentuan besarnya pengaruh tersebut dilakukan dengan menerapkan analisis regresi sederhana. Dalam analisis regresi sederhana ini, hubungan fungsional antara variabel bebas $\mathrm{X}$ dengan variabel $\mathrm{Y}$ dinyatakan dengan model :

"Y = a + bx", dimana "a" adalah konstanta dan "b" adalah koefisien parameter X atau koefisien regresi.

\section{HASIL DAN PEMBAHASAN}

\section{Tabulasi Data}

Data utama yang dikumpulkan mengenai kemampuan individu menilai informasi dan minat mahasiswa akuntansi dalam menggunakan internet sebagai sumber pustaka. Setelah data terkumpul, selanjutnya dilakukan pentabulasian data sesuai kebutuhan. Hal ini dilakukan dengan tujuan untuk mempermudah dilakukannya pengolahan data, misalnya untuk tes validitas, tes relibilialitas serta pengolahan lainnya untuk pengujian hipotesis.

\section{Data Utama}

Data utama akan dianalisis untuk menguji hipotesis yang diajukan. Dalam hal ini yang merupakan data utama adalah data mengenai kemampuan individual menilai informasi dan minat mahasiswa akuntansi dalam menggunakan internet sebagai sumber pustaka. Untuk keperluan tersebut data yang terkumpul ditabulasi sesuai dengan kebutuhan secara lengkap di lampiran 1, 2, 3, 4, 5 dan 6.

\section{Pengujian data}

Suatu anggapan bahwa data yang dianalisis harus valid dan reliabel, harus dipahami dengan baik sebab tidak menutup kemungkinan walaupun kedua syarat tersebut telah terpenuhi dengan baik masih saja terdapat kesalahan, misalnya kesalahan lain yang muncul. Kesalahan itu mucul karena faktor eksternal yang tidak dapat dikendalikan oleh peneliti. Seperti jawaban asal - asalan atau ketidakjujuran responden dalam menjawab pertanyan pertanyaan yang diajukan. Oleh karena itu untuk mengeliminasi beberapa kemungkinan tersebut diatas digunakan uji validitas dan reliabilitas. 


\section{Uji Validitas}

Suatu angket dikatakan Valid (sah) jika pertanyaan pada suatu angket mampu mengungkapkan sesuatu yang menjadi sasaran pokok pengukuran yang dilakukan dengan angket tersebut. Pada pengujian validitas dengan uji homogenitas data dan uji korelasional antara skor masing-masing butir dengan skor total (person correlation) menunjukan korelasi yang positif dan tingkat signifikansi pada level 0,001. Berdasarkan uji validitas dengan menggunakan program komputer SPSS versi 17.0

Tabel 4

Hasil Uji Validitas

\begin{tabular}{|c|c|c|c|c|}
\hline No & Variabel & Kisaran Korelasi & Signifikansi & Keterangan \\
\hline 1 & Kemampuan Individual & $0,740-0,800$ & 0,01 & Valid \\
\hline 2 & Computer Self Eficacy & $0,510-0705$ & 0,01 & Valid \\
\hline 3 & Knowledge of Search Domain & $0,898-0,910$ & 0,01 & Valid \\
\hline 4 & Perceived Usefulness & $0,664-0,831$ & 0,01 & Valid \\
\hline 5 & Perceived Ease of Use & $0,732-0,832$ & 0,01 & Valid \\
\hline 6 & Behavioral Intention & $0,775-0,863$ & 0,01 & Valid \\
\hline
\end{tabular}

Sumber : data primer diolah SPSS 2010

\section{Uji Reliabilitas}

Karena semua butir pada uji validitas diatas sudah dinyatakan valid, maka analisis dilanjutkan dengan uji reliabilitas. Jika uji uji validitas ditujukan untuk mengungkapkan konsitensi internal butir dalam mengungkapkan faktor, uji reliabilitas bermaksud mengungkapkan stabilitas internal jawaban dalam satu faktor. Satu angket dikatakan reliabel jika jawaban seseorang terhadap pertanyaan - pertanyaan dalam angket adalah konsisten atau stabil dari waktu ke waktu. Pada uji reliabilitas, konsistensi internal koefisiensi Cronbach's Alpha menunjukan tidak ada koefisien yang kurang dari nilai batas minimal 0,60 .

Tabel 5

Hasil Uji Reliabilitas

\begin{tabular}{|c|c|c|c|}
\hline No. & Variabel & Nilai Cronbach's Alpha & Keterangan \\
\hline 1 & Kemampuan Individual & 0,756 & Reliabel \\
\hline 2 & Computer Self Eficacy & 0,740 & Reliabel \\
\hline 3 & Knowledge of Search Domain & 0,776 & Reliabel \\
\hline 4 & Perceived Usefulness & 0,730 & Reliabel \\
\hline 5 & Perceived Ease of Use & 0,763 & Reliabel \\
\hline 6 & Behavioral Intention & 0,775 & Reliabel \\
\hline
\end{tabular}

Sumber : data primer diolah SPSS 2010

\section{Uji Hipotesis}

Dalam rangka pengujian hipotesis ini digunakan analisis regresi sederhana dengan menggunakan bantuan program komputer SPSS versi 17.0. pada analyze regression linier. Digunakannya analisis regresi sederhana ini karena dalam penelitian ini hanya ada satu variabel independent. 


\section{KESIMPULAN DAN SARAN}

\section{Kesimpulan}

Penelitian yang dilakukan terhadap mahasiswa akuntansi di Universitas Bandar Lampung ini bertujuan untuk mengetahui pengaruh besarnya kemampuan individual menilai informasi terhadapa minat mahasiswa akuntansi dalam menggunakan internet sebagai sumber pustaka. Penelitian ini memberi hasil bahwa kemampuan individual yang tinggi dalam menilai informasi dapat meningkatkan minat mahasiswa akuntansi dalam menggunakan internet tersebut. Kesimpulan ini di dukung oleh hasil uji hipotesis pada bab IV yang menyatakan bahwa variabel independent (kemampuan individual) berpengaruh secara signifikan terhadap variabel dependent (minat mahasiswa). Dengan demikian hasil penelitian ini menerima hipotesis yang menyatakan bahwa : "kemampuan individual menilai informasi yang tinggi akan meningkatkan minat mahasiswa akuntansi dalam menggunakan internet sebagai sumber pustaka". Hal ini sama dengan penelitian Venkatesh dan Davis (1996), Igbaria dan Iivari (1995), Hong et al. (2002) juga menunjukkan bahwa kemampuan individual (computer self efficacy dan knowledge search domain) berpengaruh berpengaruh positif dan signifikan terhadap niat mahasiswa menggunakan internet internet sebagai sumber pustaka dengan perceived ease of use sebagai mediasi.

\section{Saran}

Berdasarkan analisa yang dilakukan penulis pada Universitas Bandar Lampung membuktikan adanya pengaruh kemampuan individual menilai informasi terhadap minat mahasiswa akuntansi dalam menggunakan internet sebagai sumber pustaka, namun penelitian ini tidak lepas dari keterbatasan - keterbatasan.maka penulis mengemukakan saran sebagai berikut ;

Pertama, data penelitian dihasilkan dari penggunaan istrument yang mendasarkan pada persepsi jawaban responden atau adanya faktor subyektifitas. Hal ini cenderung menimbulkan liniency bias, serta menimbulkan masalah jika persepsi responden berbeda dengan keadaan yang sesungguhnya. Kedua, penelitian ini hanya menerapkan metode survei melalui kuesioner. Peneliti tidak melakukan wawancara dan terlibat secara langsung aktivitas mahasiswa akuntansi dalam mencari sumber pustaka dengan menggunakan internet sebagai media, sehingga kesimpulan yang dikemukakan hanya berdasarkan pada data yang terkumpul melalui penggunaan instrumen secara tertulis.

Ketiga, lingkup penelitian ini dibatasi oleh lokasi atau daerah penelitian dan ukuran sampel. Hasil penelitian ini mungkin berbeda jika mahasiswa akuntansi dari universitas lain di Indonesia dimasukkan dalam sampel penelitian. Keempat, peneliti tidak dapat mengukur kemungkinan nonresponden bias terhadap hasil penelitian ini (jawaban nonresponden kemungkinan berbeda dengan jawaban responden dalam penelitian ini). 


\section{DAFTAR PUSTAKA}

Ajzen, I. From intentions to actions: A theory of planed behavior. In J. Kuhl and J. Beckmann (eds.). Action Control: From Cognition to Behavior. New York: SpringerVerlag.1985, pp. 11-39.

Bailey. James E. and Sammy W, Pearson, "Development of a Tool for Measuring and Analyzing Computer User Satisfaction." Management Science, (29:5), 1983, pp. 530-545

Darsono Li. "Examining Information Technology Acceptance By Individual Professionals. ”Gadjah Mada Internatioal Jounal of Business, (7:2), 2005, pp.155178

Davis, F. D. "Perceivedd Usefulness, Perceivedd Ease of Use, and End User Acceptance of Information Technology,” MIS Quarterly (13:3), 1989, pp. 319-340.

DeLone, W.H., and Ephraim R. Mclean, "Information System Success: The Quest for the Dependent Variable”. Information System Research, 1992, pp. 60-95.

Ferdinand, Augusty. Structural Equation Modelling dalam Penelitian Manajemen, Aplikasi Model-model rumit dalam penelitian untuk tesis Magister dan Disertasi Doktor. Badan Penerbit Universitas Diponegoro, Semarang. 2006.

Ghozali. Aplikasi Analisis Multivariate dengan Program SPSS. Badan Penerbit Universitas Diponegoro. Semarang. 2006.

Ghozali. "Model Persamaan Struktural : Konsep Aplikasi dengan AMOS 16,0." Badan Penerbit Universitas Diponegoro. 2008.

Gordin, D.L. et.al. "Using the WorldWideWeb to Build Learning Communities".Northwestern University Magazine, April, 1995. pp1-17.

Hair, J.F., R.E. Anderson., R.L. Tatham, and W.C. Black. Multivariate data Analysis. Prentice Hall, Fourth edition, 1998.

Hartono, Jogiyanto, Sistem Informasi Keperilakuan. Penerbit Andi, 2007.

Hong W, J.Y.L. Thong, W.M. Wong dan K.Y. Tam. "Determinants of User Acceptance of Digital Libraries: An Empirical Exaniation of Individual Differences and System Characteristics.” Journal of Management Information System, (18:3), 2002. pp.97124

Hsu M.H dan Chiu C.M. "Predicting Electronic Service Continuance With a Decomposed Theory of Planned Behavior”. Behavior and Information Technology (23:5), 2004. pp. 359-373

Hu. P.J, P.Y.K. Chau, O.R. Liu Sheng dan kK.Y Tam. "Examining the Technology Acceptance Model Using Physician Acceptance of Telemedicine technology." Journal of Management Information System, (16:2), 1999, pp.91-112 
Istianingsih dan Setyo Hari Wijanto. "Pengaruh Kualitas Sistem Informasi, Perceived usefulness, dan Kualitas Informasi Terhadap Kepuasan Pengguna Akhir Software Akuntansi “. Simposium Nasional Akuntansi. 2008.

Li, C. 1997. “ERP packages: What's next?”,Information System Management, 16(3), 31-35.

Li, Y. N., Tan, K. C. \& Xie, M. Measuring web-based service quality, Total Quality Management, (13:5), 2002, pp. 685-700.

Lin, J. C. C. \& Lu, H. P. Towards an understanding of the behavioural intention to use a web site, International Journal of Information Management, (20:3), 2002, pp. 197-208.

Liu, C. K. \& Arnett, P. Exploring the factors associated with web site success in the context of electronic commerce, Information and Management, (38:1), 2000, pp. 23-33.

Rai, A., Lang, S.S. and Welker, R.B., "Assessing the Validity of IS Success Models: An Empirical Test and Theoretical Analysis”, Information System Research, Vol.13, No.1. 2002, pp. 29-34. 